\title{
Cardiovascular risk factors and frontotemporal dementia: a case-control study
}

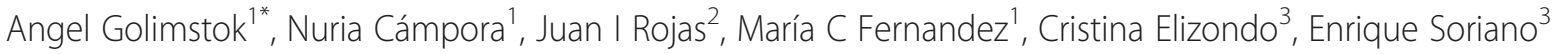 \\ and Edgardo Cristiano ${ }^{2}$
}

\begin{abstract}
Cardiovascular risk factors (CRF) were widely described as related to dementia. There are very few studies regarding this association in FTD. The objective of the study was to compare the frequency of CRF in our population with FTD and controls. 100 consecutive subjects with FTD diagnosis according to Lund-Manchester clinical criteria and 200 controls matched by age and sex were included between January 2003 to February 2007 at the Cognitive and Behavior Unit of Hospital Italiano de Buenos Aires. Clinical evaluation, laboratory tests, brain images (CT/MRI), neuropsychological and neuropsychiatric assessment were performed. Multiple regression analysis was performed to analyze the association in CRF between FTD patients vs. controls. The mean age in FTD was $69.7 \pm 0.9$ vs. $70.1 \pm 0.8$ in controls ( $p$ 0.12). No difference in gender was observed between cases and controls. No differences were identified between patients and controls regarding hypertension (HTA) $(65 \%$ vs. $67,3 \%$ p 0.44); dyslipidemia ( $57 \%$ vs. $54.7 \%$ p 0.74); obesity ( $39 \%$ vs. $27.6 \%$ p 0.14 ) and hypothyroidism ( $26 \%$ vs. $17.1 \%$ p 0.1 ). A significant difference was observed for Diabetes Mellitus (39\% vs. $22.6 \%$ p 0.001). In our population, Diabetes Mellitus was associated as an independent risk factor for FTD. To our knowledge this is the first report in which CRF were evaluated prospectively in FTD patients. More studies are needed to confirm this finding in larger populations.
\end{abstract}

Keywords: Cardiovascular risk factors, Frontotemporal dementia, Dementia, FTD, Diabetes, DBT, DM

\section{Introduction}

Frontotemporal dementia (FTD) is a broad descriptive term referring to several distinct clinical syndromes characterized by progressive neurologic deterioration with prominent behavioral and language impairment [1,2]. There are three classic clinical syndromes: behavioral variant frontotemporal lobar degeneration (bvFTLD), semantic dementia (a fluent aphasia with loss of word meaning), and progressive non-fluent aphasia (a disorder typified by effortful, nonfluent speech). Frontotemporal dementia (FTD) accounts for $5-15 \%$ of all dementia and is the second commonest cause in the presenile age group [3,4]. About $20-40 \%$ of FTD cases are familial in series from specialist referral centers [5-8]. Among the FTD syndromes, bvFTLD is the most heritable, and semantic dementia the least heritable, perhaps accounting for recent evidence suggesting that a high proportion of patients with semantic dementia present

\footnotetext{
* Correspondence: angel.golimstok@hospitalitaliano.org.ar

${ }^{1}$ Cognitive and Behavior Unit, Department of Neurology, Hospital Italiano de Buenos Aires, Perón 4272, 1411 Buenos Aires, Argentina

Full list of author information is available at the end of the article
}

over the age of 65 years [9]. A knowledge of risk factors for FTD may provide clues to the underlying pathophysiology. There is increasing interest in genetic factors that may predispose to the disease, and five genetic loci for causal mutations have been identified, all showing $100 \%$ penetrance. However, approximately $60 \%$ of patients with FTD have no family history of dementia and are considered to be sporadic cases. Prospective studies evaluating nongenetic risk factors for this condition are lacking.

A large number of factors have been associated with increased risk of dementia in general, and cardiovascular risk factors are the most consistently reported. A history of diabetes, hypertension, smoking, obesity, and dyslipidemia have all been found to increase risk. Although these risk factors are well studied in Alzheimer's Disease (AD), Vascular Dementia (VD) and Lewy Body Disease (LBD) [10-16], very few reports are found in FTD.

We therefore undertook a case-control study to analyze the association of cardiovascular risk factors and FTD. 


\section{Methods}

Site

This study was conducted at the Italian Hospital Medical Care Program (IHMCP) in Buenos Aires, Argentina with approval from the institutional Review Board of the IHMCP research committee. IHMCP provides comprehensive medical and health services to over 150,000 members primarily located in the urban areas around the Autonomous City of Buenos Aires, Argentina. The IHMCP population characteristics are closely representative of the metropolitan population of the Autonomous City of Buenos Aires, as demonstrated by 2001 census data in a series of socio-economic categories (Table 1). The period of the study was conducted from 2003 through 2007. Patients and controls were analyzed after informed consent was signed. In demented patients, researchers ensure that patients fully understand and appreciate the consequences of their participation throughout the course of the study. When a demented patient was not able to make informed decisions, the researchers ensured that the substitute decision maker (a direct family member) made the choice regarding patient wishes. Patients with dementia and controls were recruited from the membership of the IHMCP, a large prepaid health maintenance organization model.

\section{Patients}

Our study included patients who met Lund and Manchester criteria [17]. All patients were evaluated and diagnosed by a trained neurologist. Clinical evaluation, laboratory tests, brain images (CT/MRI) and neuropsychological-neuropsychiatric assessment were performed. Routine clinical investigations were conducted to exclude

Table 1 Socioeconomic level and ethnic origin of inhabitants of the Autonomous City of Buenos Aires and IHMCP affiliates, based on the 2001 Argentinean census

\begin{tabular}{lll}
\hline & City of Buenos Aires (\%) & IHMCP (\%) \\
\hline Upper class & 10 & 5 \\
Upper middle class & 16 & 19.4 \\
Middle class & 30 & 37.5 \\
Lower middle class & 21 & 25.6 \\
Lower class & 17 & 12.5 \\
Poor & 13 & 0 \\
Total & 100 & 100 \\
Ethnic origin & & \\
Caucasian & 92 & 95.5 \\
Asian & 4 & 2 \\
African American & 1 & 0.5 \\
Mestizos (a) & 3 & 2 \\
\hline
\end{tabular}

IHMCP, Italian Hospital Medical Care Program. (a) Mestizos (Spanish term used to designate people of mixed European and Amerindian ancestry living in the region of Latin America). reversible causes of dementia. Patients were excluded if formal examination showed evidence of any other brain disorder, physical and/or mental illness that contributed considerably to the clinical picture. Patient selection was strictly consecutive and included all prevalent cases in the center who met previous criteria.

\section{Controls}

Controls were matched to patients with FTD by sex, age and geographic area of residence. For each patient, we identified two people from the same general practice list of the same sex and age. If a potential control was ineligible, we approached the next closest in age. Controls were never duplicated. Records of potential controls were reviewed by a neurologist to exclude those controls in which the presence of dementia of any type or any other neurological disease was suspected before or during the index year (year of diagnosis of dementia in the matched case). The list of the entire population from which potential controls were randomly drawn was provided by the record database system of the IHMCP epidemiological center, and control subjects were selected for cases using a statistical program.

\section{Ascertainment of cardiovascular risk factors}

In order to assess and compare the frequency of cardiovascular risk factors in our population with FTD and controls, the medical records obtained during a 4-year period (1 January 2003 to 28 February 2007) at IHMCP were examined. We confined the cardiovascular risk factor assessment to: age, sex, hypertension (HTA) (in which hypertension was defined as diastolic blood pressure $>90 \mathrm{mmHg}$ and systolic blood pressure $>140 \mathrm{mmHg}$. The diagnosis was based on medical history, current treatment and results of direct measurements performed on three different occasions during the study), dyslipidemia (TG $\geq 150 \mathrm{mg} / \mathrm{dl}$. HDL-C $<40 \mathrm{mg} / \mathrm{dL}$ for males, $<50 \mathrm{mg} / \mathrm{dL}$ for females and LDL cholesterol $>130 \mathrm{mg} / \mathrm{dl}$ ), obesity (defined when body mass index, calculated as the ratio between weight and squared height, was $>30 \mathrm{~kg} / \mathrm{m} 2$.), osteoporosis and hypothyroidism ( $\mathrm{TSH}>4.5 \mathrm{mU} / \mathrm{L}$ ) (by possible association with dyslipidemia). CVRF were considered according to CAIDE study data [18] and Diabetes (DM) (fasting plasma glucose level $\geq 7.0 \mathrm{mmol} / \mathrm{l}$ or $126 \mathrm{mg} / \mathrm{dl}$ ) according to the Rotterdam study [19].

\section{Statistical analyses}

Associations for potential cardiovascular risk factors were assessed with conditional logistic regression analyses comparing FTD and control subjects. This was done in order to identify the collection of features that displayed differences between study groups while controlling for the effects of the others. Stata 10.1 was used for this analysis. 
Ethics approval was obtained from the Ethics Committee of Hospital Italiano de Buenos Aires, Argentina. Informed consent was obtained from each case and control included.

\section{Results}

During the study period, a total of 100 cases and 200 controls were included. The mean age in FTD cases was $69.7 \pm 0.9$ vs. $70.1 \pm 0.8$ in controls (p 0.12). A total of $75 \%$ of the population was of female sex in controls vs. $68 \%$ in cases included. No sex difference was observed between cases and controls, as was expected. When the included population from the IHMCP was compared with the socioeconomic and ethnic origin data from the City of Buenos Aires, no significant differences were observed. A total of $65 \%$ of cases had hypertension, $39 \%$ obesity and 39\% fulfil diagnosis criteria for diabetes. Baseline characteristics of patients included are displayed in Table 2. When cases and controls were compared, no association in hypertension (HTN) (65\% vs. $67.3 \%$ p 0.44$)$, dyslipidemia (57\% vs. $54.7 \%$ p 0.74 ), obesity ( $39 \%$ vs. $27.6 \%$ p 0.14$)$ and hypothyroidism (26\% vs. $17.1 \%$ p 0.1$)$ were found in the logistic regression analyses performed. However, we observed significant association in the logistic regression analysis in Diabetes Mellitus type II (DM2) between cases and controls (39\% vs. $22.6 \% \mathrm{p}=0.001)$ (Table 3).

\section{Discussion}

In this study, we examined the frequency of 6 possible risk factors associated with the likelihood of FTD. Among the CVRF we did not include tobacco, as it was very difficult to verify the data in our control group records. A clinical diagnosis of FTD was associated with a greater likelihood of having a history of DM2. This is a very significant finding in our population whereas in Latin America, diabetes is a highly prevalent disease in over 45 years, with higher percentages of cases than the rest of the world [20]. In two previous retrospective

Table 2 Baseline Characteristics of included patients*

\begin{tabular}{lll}
\hline Variable & Controls & Cases \\
& $\mathbf{N = 2 0 0}$ & $\mathbf{N = 1 0 0}$ \\
\hline Female sex $\mathbf{n}(\%)$ & $150(75)$ & $68(68)$ \\
Mean age (SD), years & $70.1 \pm 0.8$ & $69.7 \pm 0.9$ \\
DM2 N (\%) & $45(22.6)$ & $39(39)$ \\
HTN N (\%) & $134(67.3 \%)$ & $65(65 \%)$ \\
Obesity N (\%) & $55(27.6 \%)$ & $39(39 \%)$ \\
Dyslipidemia N (\%) & $109(54.7 \%)$ & $57(57 \%)$ \\
Hypothyroidism N (\%) & $34(17.1)$ & $34(26)$ \\
Osteoporosis N (\%) & $40(20.1 \%)$ & $21(21 \%)$ \\
\hline
\end{tabular}

*Data shown as baseline descriptive variables. Comparisons between groups were made by logistic regression analyses. DM: Diabetes mellitus, HTN: hypertension.
Table 3 Logistic regression analyses

\begin{tabular}{lll}
\hline Variable & $\mathbf{P}$ & OR $\mathbf{( 9 5 \% ~ C l )}$ \\
\hline DM2 & $\mathbf{0 . 0 0 1}$ & $\mathbf{4 . 8}(\mathbf{2 . 1}-\mathbf{6 . 5})$ \\
HTN & 0.44 & $1.3(0.8-2.1)$ \\
Obesity & 0.14 & $1.2(0.6-1.8)$ \\
Dyslipidemia & 0.74 & $1.5(0.5-2.2)$ \\
Hypothyroidism & 0.10 & $1.8(0.9-3.1)$ \\
Osteoporosis & 0.36 & $1.3(0.7-2.5)$ \\
\hline
\end{tabular}

DM: Diabetes mellitus, HTN: hypertension.

case-control studies the prevalence of this antecedent was higher in patients with FTD, but the multivariate analysis showed there were no statistically significant differences [5,21]. The explanation for this association remains unclear, but several findings from clinical and experimental research encourage the formulation of hypotheses about the underlying mechanisms. Previous prospective, large, population-based cohort studies have found that diabetes is associated with an increased risk of cognitive decline and dementia $[19,22,23]$.

The principal finding of these studies was that diabetes is associated with a $50-100 \%$ increase in risk of $\mathrm{AD}$ and of dementia overall and a 100-150\% increased risk of vascular dementia. However, limitations in clinical diagnostic criteria do not allow the confirmation of a differential effect on dementia subtype [24].

Type 3 diabetes mellitus (DM3) was described as corresponding to a chronic insulin resistance plus insulin deficiency state largely confined to the brain that can overlap with DM2 [25]. As It has been proposed that DM3 represents a major pathogenic mechanism of $A D$ neurodegeneration [25-26], in the last years have been made several studies demonstrating the biological substrate of this mechanism [27-29].

As was expected, such studies have not been performed in FTD because the association with DM has not been reported so far.

Areas of active research are the direct effects of hyperinsulinemia and insulin resistance in the brain. Abnormal insulin sensitivity was found to be associated to deficits in speech production (verbal fluency), reduction of gray matter volume in the temporal lobe brain regions related to language function and lower total brain size as well [23].

As language processing is usually impaired in patients with FTD [30,31], these findings should be analyzed. There is evidence that Central Nervous System (CNS) insulin signaling enhances synaptic long-term potentiation [32], modulates the action of neurotransmitters involved in behavior and cognitive processing (e.g., norepinephrine and dopamine) [33] and attenuates cortisol secretion [34]. Thus, we can infer that more than one mechanism is involved in the pathophysiology of these changes and that 
DM2 may represent a metabolic state in which neuroprotective and neuromodulatory effects of insulin in the CNS are disrupted. This may be particularly true in FTD because the process of neurodegeneration takes place in brain regions with high densities of insulin receptors that are sensitive to changes in CNS insulin signaling, such as in the temporal lobes [35]. Analogous findings related to similar pathologies demonstrating reduced cerebral glucose metabolic rate in frontal, parietotemporal, and cingulate brain regions support these concepts [36]. Furthermore, chronic hyperglycemia, the hallmark of DM has been shown to accelerate formations of advanced glycation end products (AGEs) that can induce tau hyperphosphorylation which, in turn, impairs synapse and memory through RAGE-mediated GSK-3 activation [37]. Tau hyperphosphorylation may be an important event in the process leading to tau intracellular aggregation and neuronal cell death in tauopathies that constitute a significant percentage of cases of FTD [38].

Supporting this concept, it is known that insulin exerts its effect through a receptor, a heterotetramer $(\alpha 2 \beta 2)$ with tyrosine kinase activity in its intracellular portion. Joining insulin extracellular $\alpha$ subunits induces a change in the conformation of $\beta$ subunits, which initiates a series of phosphorylations and activates, among others, the path of PI3-K/Akt. Activation of PKB or Akt deactivates glycogen synthase kinase-3 (GSK-3) [39-41].

Another piece of interesting data that may help to understand the meaning of the association between DM2 and FTD are the studies reporting brain atrophy in DM2 patients mainly exhibiting gray and white matter atrophy in right temporal lobe, and this finding bears out that DM2 could lead to subtle diabetic brain structural changes in patients without dementia or macrovascular complications [42]. This again corroborates findings in adults with DM2, where prefrontal volume reductions and global cerebral atrophy have been reported. Patients with diabetes, both with and without depression, had smaller total brain gray matter volumes when compared with the control subjects after controlling for age, intracranial volume and years of education. This group also had smaller gray matter volumes in the anterior cingulate and orbitofrontal regions when compared with the controls after additionally controlling for total gray matter volume. The depressed and nondepressed diabetic groups did not differ in any neuroimaging measure in this series of patients reported [43].

Another report showed that greater insulin resistance as indexed by HOMA-IR was associated with an AD-like pattern of reduced cerebral metabolic rate of glucose in frontal, temporal-parietal, and cingulate regions in adults with pre-diabetes or DM2 [36].

Interestingly, a similar pattern of brain regional glucose metabolism has been recently described in FTD as well
[44]. Obesity was reported as related to brain atrophy, cognitive deficit [45-47] and as a risk factor for other types of dementia [48]. However, in our study we found no statistically significant differences between groups in the multivariate analysis. So, we suggest that obesity was not an independent risk factor for FTD, in this population. As in previous reports [21,49], our study showed that the percentage of hypothyroidism was higher in cases than in controls, but the difference was not significant in the multivariate analysis. Mental studies have shown that splicing of juvenile and adult tau mRNA variants is regulated by thyroid hormone. As shown by the in situ hybridization experiments, thyroid hormone seems to regulate the levels of tau mRNA in the cerebellum by changing the rate of migration of the granule cell. Another effect of this hormone on tau expression is to modify the timing of the splicing mechanism that during development allows differential selection of exons present in the tau gene. It remains to be determined whether the effects of thyroid hormone on cell migration and on the splicing mechanism are related. It is also not clear whether the post-transcriptional effect of thyroid hormone on the splicing mechanism is direct or, more probably, mediated by gene expression. It is widely accepted that the cellular actions of thyroid hormone are mediated by nuclear receptors that bind to thyroid hormone response elements associated with target genes and stimulate or inhibit expression of these genes. The data reported herein suggest that, at least for the production of various tau protein isoforms during brain development, the splicing mechanism is regulated by thyroid hormone. Even if this effect of thyroid hormone is indirect it may explain the impairment in neurite outgrowth induced by thyroid hormone deficiency in the newborn [50]. The cause of one of the most common syndromes of frontotemporal dementia are the tauopathies, and thyroid hormone level abnormalities in frontotemporal dementia were found to be frequent (38\%) in a previous study [51]. As thyroid disorders may be related to FTD, further studies to elucidate the mechanisms of this association are needed. The other factors studied such as hypertension, dyslipidemia and osteoporosis were not shown to be risk factors for FTD, which is consistent with results of previous reports. We include osteoporosis among risk factors because it has been reported previously that the vitamin $\mathrm{D}$ deficiency is a common finding in dementia [52].

The strength of our study, with a considerable number of patients and controls, was that patients were fully studied and followed over time to verify the diagnosis in their evolution. Unfortunately, we have no pathology of our cases, and controls were not studied directly but through examination of medical records. This last limitation prevented us to compare the images and cognitive scores between the two groups. 
Our findings open the door to prospective studies with pathology that distinguish between different variants included in the diagnosis of FTD and that examine other factors not analyzed in the present study.

\section{Competing interest}

A. Golimstok, C. Fernández, N. Cámpora, C Elizondo and E. Soriano declares no conflict of interest.

Juan Ignacio Rojas has received honoraria from Novartis as a scientific advisor. He has received travel grants and attended courses and conferences on behalf of Merck-Serono Argentina, Novartis Argentina.

Edgardo Cristiano has received fees for consultations as a scientific advisory board member and for travel to meetings, conferences and clinical trials of the following companies: Avanir, Bayer, Biogen, Merck, Novartis and Teva.

\section{Authors' contributions}

AG, NC, MCF and EC design and study analysis. JIR, CE, ES statistical design and analysis. All authors read and approved the final manuscript.

\section{Author details}

${ }^{1}$ Cognitive and Behavior Unit, Department of Neurology, Hospital Italiano de Buenos Aires, Perón 4272, 1411 Buenos Aires, Argentina. ²Department of Neurology, Hospital Italiano de Buenos Aires, Buenos Aires, Argentina.

${ }^{3}$ Epidemiology Department, Hospital Italiano de Buenos Aires, Buenos Aires, Argentina.

Received: 21 March 2014 Accepted: 13 June 2014

Published: 21 June 2014

\section{References}

1. The Lund and Manchester Groups: Clinical and neuropathological criteria for frontotemporal dementia. J Neurol Neurosurg Psychiatry 1994, 57(4):416-418.

2. McKhann GM, Albert MS, Grossman M, Miller B, Dickson D, Trojanowski JQ Pick's D, Work Group on Frontotemporal: Clinical and pathological diagnosis of frontotemporal dementia: report of the Work Group on Frontotemporal Dementia and Pick's Disease. Arch Neurol 2001, 58(11):1803-1809.

3. Bird T, Knopman D, VanSwieten J, Rosso S, Feldman H, Tanabe H, Graff-Raford N, Geschwind D, Verpillat P, Hutton M: Epidemiology and genetics of frontotemporal dementia/Pick's disease. Ann Neurol 2003, 54(Suppl 5):S29-S31. doi:10.1002/ana.10572.

4. Feldman H, Levy AR, Hsiung GY, Peters KR, Donald A, Black SE, Bouchard RW, Gauthier SG, Guzman DA, Hogan DB, Kertesz A, Rockwood K, Group AS: A Canadian cohort study of cognitive impairment and related dementias (ACCORD): study methods and baseline results. Neuroepidemiology 2003, 22(5):265-274. doi:71189.

5. Rohrer JD, Guerreiro R, Vandrovcova J, Uphill J, Reiman D, Beck J, Isaacs AM, Authier A, Ferrari R, Fox NC, Mackenzie IR, Warren JD, de Silva R, Holton J, Revesz T, Hardy J, Mead S, Rossor MN: The heritability and genetics of frontotemporal lobar degeneration. Neurology 2009, 73(18):1451-1456. doi:10.1212/WNL.0b013e3181bf997a.

6. Seelaar H, Kamphorst W, Rosso SM, Azmani A, Masdjedi R, de Koning I, Maat-Kievit JA, Anar B, Donker Kaat L, Breedveld GJ, Dooijes D, Rozemuller $J M$, Bronner IF, Rizzu P, van Swieten JC: Distinct genetic forms of frontotemporal dementia. Neurology 2008, 71(16):1220-1226. doi:10.1212/01.wnl.0000319702.37497.72.

7. Rohrer JD, Warren JD: Phenotypic signatures of genetic frontotemporal dementia. Curr Opin Neurol 2011, 24(6):542-549. doi:10.1097/WCO. ob013e32834cd442.

8. Chow TW, Miller BL, Hayashi VN, Geschwind DH: Inheritance of frontotemporal dementia. Arch Neurol 1999, 56(7):817-822.

9. Hodges JR, Mitchell J, Dawson K, Spillantini MG, Xuereb JH, McMonagle P, Nestor PJ, Patterson K: Semantic dementia: demography, familial factors and survival in a consecutive series of 100 cases. Brain 2010, 133(Pt 1):300-306. doi:10.1093/brain/awp248.

10. Sharp SI, Aarsland D, Day S, Sonnesyn H, Alzheimer's Society Vascular Dementia Systematic Review G, Ballard C: Hypertension is a potential risk factor for vascular dementia: systematic review. Int I Geriatr Psychiatry 2011, 26(7):661-669. doi:10.1002/gps.2572.
11. Anstey KJ, Cherbuin N, Budge M, Young J: Body mass index in midlife and late-life as a risk factor for dementia: a meta-analysis of prospective studies. Obes Rev 2011, 12(5):e426-e437. doi:10.1111/j.1467789X.2010.00825.X

12. Lu FP, Lin KP, Kuo HK: Diabetes and the risk of multi-system aging phenotypes: a systematic review and meta-analysis. PLoS One 2009, 4(1):e4144. doi:10.1371/journal.pone.0004144.

13. Peters R, Poulter R, Warner J, Beckett N, Burch L, Bulpitt C: Smoking, dementia and cognitive decline in the elderly, a systematic review. BMC Geriatr 2008, 8:36. doi:10.1186/1471-2318-8-36.

14. Anstey KJ, Lipnicki DM, Low LF: Cholesterol as a risk factor for dementia and cognitive decline: a systematic review of prospective studies with meta-analysis. Am J Geriatr Psychiatry 2008, 16(5):343-354. doi:10.1097/JGP.0b013e31816b72d4

15. Frigerio R, Fujishiro H, Maraganore DM, Klos K, DelleDonne A, Heckman MG, Crook JE, Josephs KA, Parisi JE, Boeve BF, Dickson DW, Ahlskog JE: Comparison of risk factor profiles in incidental Lewy body disease and Parkinson disease. Arch Neurol 2009, 66(9):1114-1119. doi:P10.1001/archneurol.2009.170.

16. Boot BP, Orr CF, Ahlskog JE, Ferman TJ, Roberts R, Pankratz VS, Dickson DW, Parisi J, Aakre JA, Geda YE, Knopman DS, Petersen RC, Boeve BF: Risk factors for dementia with Lewy bodies: a case-control study. Neurology 2013, 81(9):833-840. doi:10.1212/WNL.0b013e3182a2cbd1.

17. Neary D, Snowden JS, Gustafson L, Passant U, Stuss D, Black S, Freedman M, Kertesz A, Robert PH, Albert M, Boone K, Miller BL, Cummings J, Benson DF: Frontotemporal lobar degeneration: a consensus on clinical diagnostic criteria. Neurology 1998, 51(6):1546-1554.

18. Rusanen M, Rovio S, Ngandu T, Nissinen A, Tuomilehto J, Soininen H, Kivipelto M: Midlife smoking, apolipoprotein E and risk of dementia and Alzheimer's disease: a population-based cardiovascular risk factors, aging and dementia study. Dement Geriatr Cogn Disord 2010, 30(3):277-284. doi:10.1159/000320484

19. Ott A, Stolk RP, van Harskamp F, Pols HA, Hofman A, Breteler MM: Diabetes mellitus and the risk of dementia: The Rotterdam Study. Neurology 1999, 53(9):1937-1942.

20. Sandoval CM: Importancia global y local de la diabetes mellitus tipo 2 . Rev Hosp Clín Univ Chile 2012, 23:185-190.

21. Rosso SM, Landweer EJ, Houterman M, Donker Kaat L, van Duijn CM, van Swieten JC: Medical and environmental risk factors for sporadic frontotemporal dementia: a retrospective case-control study. J Neurol Neurosurg Psychiatry 2003, 74(11):1574-1576.

22. Gregg EW, Yaffe K, Cauley JA, Rolka DB, Blackwell TL, Narayan KM, Cummings SR: Is diabetes associated with cognitive impairment and cognitive decline among older women? Study of Osteoporotic Fractures Research Group. Arch Intern Med 2000, 160(2):174-180.

23. Benedict C, Brooks SJ, Kullberg J, Burgos J, Kempton MJ, Nordenskjold R, Nylander R, Kilander L, Craft S, Larsson EM, Johansson L, Ahlstrom H, Lind L, Schioth HB: Impaired insulin sensitivity as indexed by the HOMA score is associated with deficits in verbal fluency and temporal lobe gray matter volume in the elderly. Diabetes Care 2012, 35(3):488-494. doi:10.2337/dc11-2075.

24. Ahtiluoto S, Polvikoski T, Peltonen M, Solomon A, Tuomilehto J, Winblad B, Sulkava R, Kivipelto M: Diabetes, Alzheimer disease, and vascular dementia: a population-based neuropathologic study. Neurology 2010, 75(13):1195-1202. doi:10.1212/WNL.0b013e3181f4d7f8.

25. Steen E, Terry BM, Rivera EJ, Cannon JL, Neely TR, Tavares R, Xu XJ, Wands JR, de la Monte SM: Impaired insulin and insulin-like growth factor expression and signaling mechanisms in Alzheimer's disease-is this type 3 diabetes? J Alzheimers Dis 2005, 7(1):63-80.

26. Rivera EJ, Goldin A, Fulmer N, Tavares R, Wands JR, de la Monte SM: Insulin and insulin-like growth factor expression and function deteriorate with progression of Alzheimer's disease: link to brain reductions in acetylcholine. J Alzheimers Dis 2005, 8(3):247-268.

27. Schubert M, Brazil DP, Burks DJ, Kushner JA, Ye J, Flint CL, Farhang-Fallah J, Dikkes $P$, Warot XM, Rio C, Corfas G, White MF: Insulin receptor substrate-2 deficiency impairs brain growth and promotes tau phosphorylation. J Neurosci 2003, 23(18):7084-7092. doi:23/18/7084.

28. Schubert M, Gautam D, Surjo D, Ueki K, Baudler S, Schubert D, Kondo T, Alber J, Galldiks N, Kustermann E, Arndt S, Jacobs AH, Krone W, Kahn CR, Bruning JC: Role for neuronal insulin resistance in neurodegenerative 
diseases. Proc Natl Acad Sci U S A 2004, 101(9):3100-3105. doi:10.1073/pnas.0308724101

29. Cukierman T, Gerstein HC, Williamson JD: Cognitive decline and dementia in diabetes-systematic overview of prospective observational studies. Diabetologia 2005, 48(12):2460-2469. doi:10.1007/s00125-005-0023-4

30. Snowden JS: Semantic dysfunction in frontotemporal lobar degeneration. Dement Geriatr Cogn Disord 1999, 10(Suppl 1):33-36. doi:51209.

31. Hillis $A E, O h S$, Ken $L$ : Deterioration of naming nouns versus verbs in primary progressive aphasia. Ann Neurol 2004, 55(2):268-275. doi:10.1002/ana.10812.

32. Lee CC, Kuo YM, Huang CC, Hsu KS: Insulin rescues amyloid beta-induced impairment of hippocampal long-term potentiation. Neurobiol Aging 2009, 30(3):377-387. doi:10.1016/j.neurobiolaging.2007.06.014.

33. Figlewicz DP, Brot MD, McCall AL, Szot P: Diabetes causes differential changes in CNS noradrenergic and dopaminergic neurons in the rat: a molecular study. Brain Res 1996, 736(1-2):54-60.

34. Chan O, Chan S, Inouye K, Vranic M, Matthews SG: Molecular regulation of the hypothalamo-pituitary-adrenal axis in streptozotocin-induced diabetes: effects of insulin treatment. Endocrinology 2001 142(11):4872-4879.

35. Havrankova J, Roth J, Brownstein M: Insulin receptors are widely distributed in the central nervous system of the rat. Nature 1978, 272(5656):827-829.

36. Baker LD, Cross DJ, Minoshima S, Belongia D, Watson GS, Craft S: Insulin resistance and Alzheimer-like reductions in regional cerebral glucose metabolism for cognitively normal adults with prediabetes or early type 2 diabetes. Arch Neurol 2011, 68(1):51-57. doi:10.1001/archneurol.2010.225.

37. Li XH, Lv BL, Xie JZ, Liu J, Zhou XW, Wang JZ: AGEs induce Alzheimer-like tau pathology and memory deficit via RAGE-mediated GSK-3 activation. Neurobiol Aging 2012, 33(7):1400-1410. doi:10.1016/j.neurobiolaging. 2011.02.003.

38. Chun W, Johnson GV: The role of tau phosphorylation and cleavage in neuronal cell death. Front Biosci 2007, 12:733-756

39. Cohen $P$ : The twentieth century struggle to decipher insulin signalling. Nat Rev Mol Cell Biol 2006, 7(11):867-873. doi:10.1038/nrm2043.

40. Cohen P, Frame S: The renaissance of GSK3. Nat Rev Mol Cell Biol 2001, 2(10):769-776. doi:10.1038/35096075.

41. Castillo-Quan Jl, Barrera-Buenfil DJ, Perez-Osorio JM, Alvarez-Cervera FJ: Depression and diabetes: from epidemiology to neurobiology. Rev Neurol 2010, 51(6):347-359.

42. Chen Z, Li L, Sun J, Ma L: Mapping the brain in type II diabetes: Voxel-based morphometry using DARTEL. Eur J Radiol 2012, 81(8):1870-1876. doi:10.1016/j.ejrad.2011.04.025.

43. Kumar A, Haroon E, Darwin C, Pham D, Ajilore O, Rodriguez G, Mintz J: Gray matter prefrontal changes in type 2 diabetes detected using MRI. J Magn Reson Imaging 2008, 27(1):14-19. doi:10.1002/jmri.21224.

44. Womack KB, Diaz-Arrastia R, Aizenstein HJ, Arnold SE, Barbas NR, Boeve BF, Clark CM, DeCarli CS, Jagust WJ, Leverenz JB, Peskind ER, Turner RS, Zamrini EY, Heidebrink JL, Burke JR, DeKosky ST, Farlow MR, Gabel MJ, Higdon R, Kawas CH, Koeppe RA, Lipton AM, Foster NL: Temporoparietal hypometabolism in frontotemporal lobar degeneration and associated imaging diagnostic errors. Arch Neurol 2011, 68(3):329-337. doi:10.1001/archneurol.2010.295.

45. Yau PL, Javier DC, Ryan CM, Tsui WH, Ardekani BA, Ten S, Convit A: Preliminary evidence for brain complications in obese adolescents with type 2 diabetes mellitus. Diabetologia 2010, 53(11):2298-2306. doi:10.1007/s00125-010-1857-y.

46. Gunstad J, Paul RH, Cohen RA, Tate DF, Spitznagel MB, Grieve S, Gordon E: Relationship between body mass index and brain volume in healthy adults. Int J Neurosci 2008, 118(11):1582-1593. doi:10.1080/00207450701392282.

47. Gunstad J, Paul RH, Cohen RA, Tate DF, Gordon E: Obesity is associated with memory deficits in young and middle-aged adults. Eat Weight Disord 2006, 11(1):e15-e19.

48. Whitmer RA, Gunderson EP, Quesenberry CP Jr, Zhou J, Yaffe K: Body mass index in midlife and risk of Alzheimer disease and vascular dementia. Curr Alzheimer Res 2007, 4(2):103-109.

49. Ott A, Slooter AJ, Hofman A, van Harskamp F, Witteman JC, Van Broeckhoven C, van Duijn CM, Breteler MM: Smoking and risk of dementia and Alzheimer's disease in a population-based cohort study: the Rotterdam Study. Lancet 1998, 351(9119):1840-1843.
50. Aniello F, Couchie D, Bridoux AM, Gripois D, Nunez J: Splicing of juvenile and adult tau mRNA variants is regulated by thyroid hormone. Proc Natl Acad Sci U S A 1991, 88(9):4035-4039.

51. Faldt R, Passant U, Nilsson K, Wattmo C, Gustafson L: Prevalence of thyroid hormone abnormalities in elderly patients with symptoms of organic brain disease. Aging 1996, 8(5):347-353.

52. Kipen E, Helme RD, Wark JD, Flicker L: Bone density, vitamin D nutrition, and parathyroid hormone levels in women with dementia. J Am Geriatr Soc 1995, 43(10):1088-1091.

doi:10.1186/2047-9158-3-13

Cite this article as: Golimstok et al.: Cardiovascular risk factors and frontotemporal dementia: a case-control study. Translational Neurodegeneration 2014 3:13.

\section{Submit your next manuscript to BioMed Central and take full advantage of:}

- Convenient online submission

- Thorough peer review

- No space constraints or color figure charges

- Immediate publication on acceptance

- Inclusion in PubMed, CAS, Scopus and Google Scholar

- Research which is freely available for redistribution

Submit your manuscript at www.biomedcentral.com/submit
C) Biomed Central 